\title{
Et spedbarns mistrivsel endte med døden
}

\author{
En gutt som ved fødselen hadde en mindre lungepunktering, døde knapt \\ fire uker gammel etter langsom vektoppgang, mistrivsel, oppkast og \\ dårlig strålekraft ved vannlating.
}

Engelsk oversettelse på www.tidsskriftet.no

Se kommentar side 1968

\author{
Paal H.H. Lindenskov* \\ uxlpaa@ous-hf.no \\ Arild Rønnestad \\ Nyfødtintensivavdelingen, Rikshospitalet \\ Kvinne- og Barneklinikken \\ Hans Skari \\ Seksjon for barnekirurgi \\ Avdeling for gastro- og barnekirurgi \\ Kreft-, kirurgi- og transplantasjonsklinikken \\ Oslo universitetssykehus
}

* Nåværende adresse:

Anestesiavdelingen, Rikshospitalet,

Akuttklinikken, Oslo universitetssykehus

Gutten ble født etter 37 ukers svangerskap med en fødselsvekt på $4030 \mathrm{~g}$ tilsvarende 75-prosentilen. Ved ultralydundersøkelse $i$ svangerskapsuke 17 fikk jordmor mistanke om forstørret urinblære, men mistanken ble avkreftet ved sykehuskontroll senere i svangerskapet. Etter fødselen var gutten kortvarig innlagt i lokal nyfødtavdeling grunnet pressende åndedrett. Det ble påvist en mindre lungepunktering.

I nyfødtperioden merket foreldrene seg at gutten hadde langsom vektoppgang og var derfor i kontakt med primærhelsetjenesten. Foreldrene observerte også at gutten hadde vannlating med svak urinstråle. Da pasienten var vel to uker gammel, ble han henvist til sykehus for et inneklemt lyskebrokk som ble reponert etter 2,5 timer.

Knapt fire uker gammel kollapset gutten $i$ hjemmet. Det skjedde etter flere døgn med mistrivsel, oppkast og manglende avføring og hvor lokal helsestasjon var konsultert. Det ble i løpet av få minutter iverksatt resuscitering av tilfeldig nærværende helsepersonell med ytterligere bistand fra luftambulansepersonell etter 25 minutter. Etter 45 minutter ble det konstatert en langsom hjerterytme på 90/min (120-160/min).

Kollaps hos barn de første uker etter fødsel kan følge av ductusavhengige hjertefeil fordi lunge- eller systemkretsløpet avhenger av ductus arteriosus. Denne virker i fosterlivet som en shunt mellom lungearterien og aorta, og vil normalt lukke seg de første dager etter fødsel, ev. forsinket ved hypoksi, acidose eller alvorlige infeksjoner. Lukking av ductus arteriosus hos nyfødte med ductusavhengige hjertefeil vil enten redusere lungesirkulasjonen og gi hypoksemi som ved pulmonalklaffatresi, eller ved ductusavhengig systemsirkulasjon lede til sirkulatorisk kollaps som ved hypoplastisk venstre hjerte-syndrom, aortastenose og aortabueanomalier. Sirkulatorisk kollaps måles som lavt blodtrykk, lavt pulstrykk med manglende perifere pulser, forsinket kapillarfylling, redusert til opphevet diurese og metabolsk laktacidose.

To andre viktige årsaker til kollaps hos barn få uker etter fødsel er systemiske bakterielle infeksjoner, såkalte «late onset sepsis», og medfødte metabolske sykdommer. Sistnevnte manifesterer seg etter frafall av morkakens vikagir energisvikt og ev. toksiske metabolitter. rierende metabolisme for enzymsvikt, noe som dersom ikke annet er angitt
Ved ankomst i sykehus var pasienten hypoterm $\left(31^{\circ} \mathrm{C}\right)$ med svakt følbar lyskepuls, kald hud, ikke målbart blodtrykk med mansjett, dilaterte pupiller og betydelig utspilt og stram abdomen. Man fant et reponibelt lyskebrokk. S-kaliumnivået var høyt (tab 1).

Hyperkalemiindusert arytmi kunne forklare primær kollaps, og inntil kaliumnivået var normalisert forekom episodiske arytmier med breddeforøkte QRS-komplekser. Man merket seg at pasienten til tross for kliniske tegn på dårlig perifer sirkulasjon og ikke målbart blodtrykk med mansjett, viste seg å ha blodtrykk $80 / 40 \mathrm{~mm} \mathrm{Hg}$ målt ved arteriekanyle i lysken. Dette er innenfor normalområdet, men blir vurdert som høyt i et bilde av sirkulatorisk kollaps.

Pasientens dilaterte pupiller ved innkomst $\mathrm{i}$ sykehus ble forklart ved adrenalin brukt under resuscitering. Alternativt kunne dette betinges av avklemming av den parasympatiske ledetråd til okulomotoriusnerven mot tentorium cerebelli. Dette kan ses ved forhøyet intrakranialt trykk forårsaket av sekundær ødemutvikling ved hypoksisk hjerneskade. Et slikt ødem utvikler seg imidlertid i løpet av dager snarere enn timer etter en hypoksisk hendelse. Ultralydunders $ø$ kelse av cerebrum ved innkomst viste heller ikke tegn til forhøyet intracerebralt trykk, ingen intracerebrale blødninger og normal intracerebral sirkulasjon ved dopplerundersøkelse.

Tabell 1 Et utvalg av pasientens blodprøveverdier. Venøse prøver og referanseverdier for nyfødte

\begin{tabular}{|c|c|c|}
\hline Blodprøver & Pasient & Referanseverdi \\
\hline CRP (mg/l) & 156 & $<4$ \\
\hline Hemoglobin (g/dl) & 8,4 & $9,0-14,0$ \\
\hline Trombocytter $\left(\cdot 10^{9} /\right.$ l) & 15 & $150-600$ \\
\hline Natrium (mmol/l) & 125 & $136-146$ \\
\hline Kalium (mmol/l) & 10,2 & $3,4-5,3$ \\
\hline Magnesium (mmol/l) & 1,5 & $0,71-0,94$ \\
\hline Fosfat (mmol/l) & 4,5 & $1,2-2,0$ \\
\hline Albumin (g/l) & 16,1 & $36-48$ \\
\hline Karbamid (mmol/l) & 54,4 & $3,2-8,1$ \\
\hline Kreatinin ( $\mu \mathrm{mol} / \mathrm{l})$ & 348 & $14-34$ \\
\hline Laktat (mmol/l) & 19 & $0,4-0,8$ \\
\hline pH (arteriell prøve) & 6,47 & $7,35-7,45$ \\
\hline Plasma-renin-aktivitet (nmol///t) & 28,6 & $0,5-1,5^{1}$ \\
\hline Plasma-aldosteron (pmol/l) & 70112 & $70-80^{1}$ \\
\hline
\end{tabular}




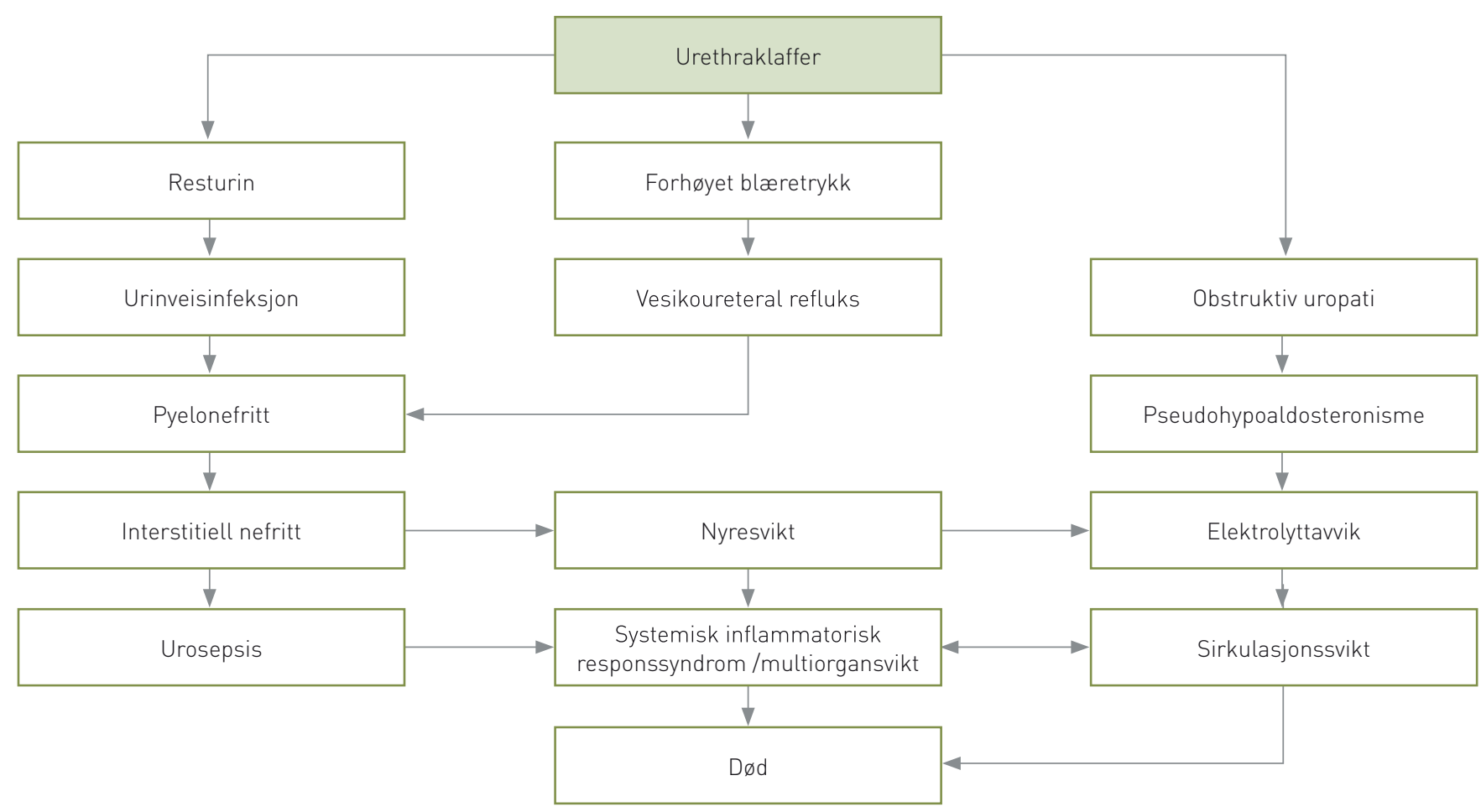

Figur 1 Mulige konsekvenser av urethraklaffer hos spedbarn. Figuren er basert på Paal H.H. Lindenskovs oppsett

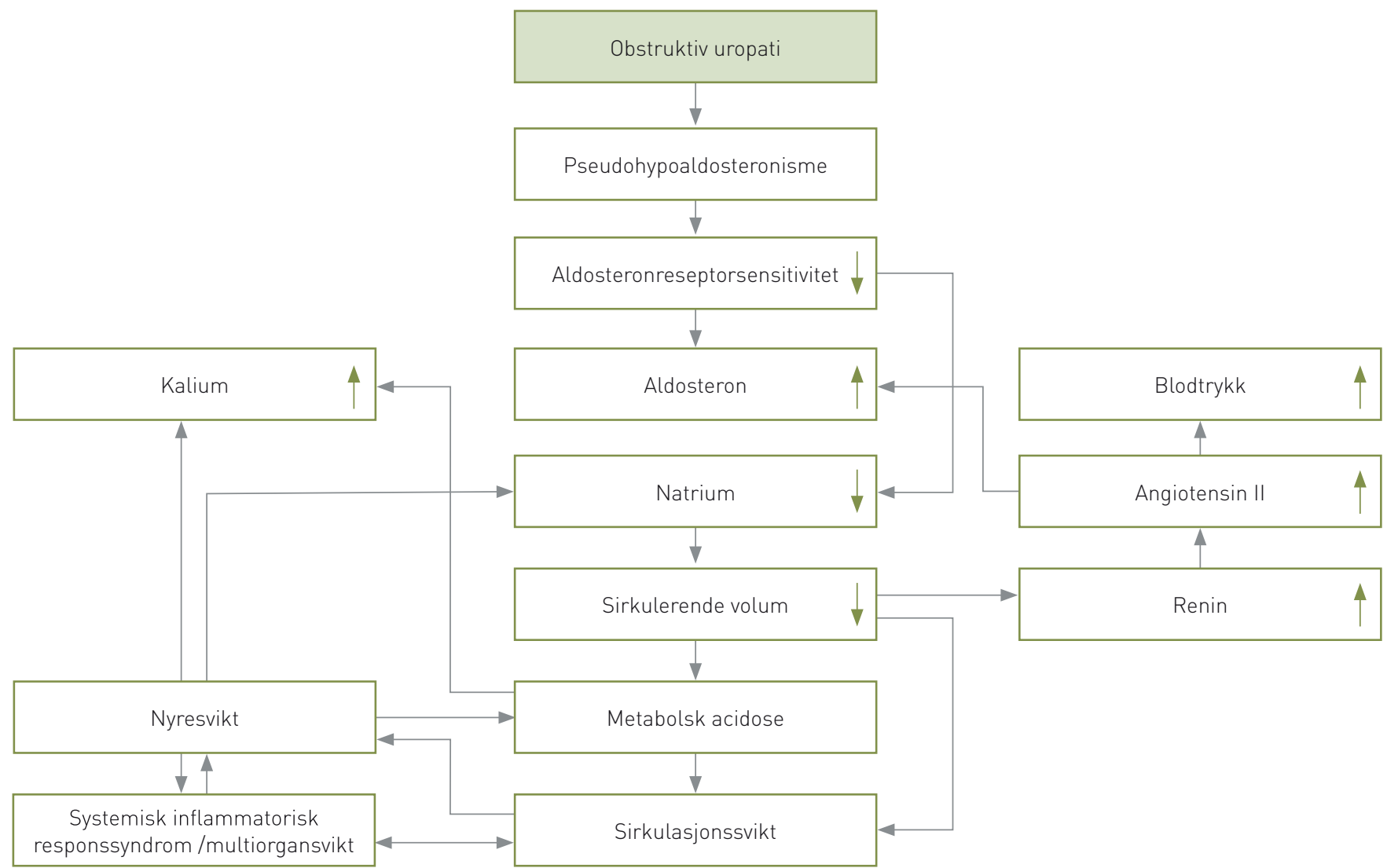

Figur 2 Patofysiologi ved obstruktiv uropati. Figuren er basert på Paal H.H. Lindenskovs oppsett 
Tabell 2 Veiledende biokjemiske profiler ved salttapende syndromer hos spedbarn. Tabellen er basert på Paal H.H. Lindenskovs oppsett

\begin{tabular}{|c|c|c|c|c|c|c|c|}
\hline & $\begin{array}{l}\text { Natrium } \\
\text { (serum) }\end{array}$ & $\begin{array}{l}\text { Salttap } \\
\text { i urin }\end{array}$ & $\begin{array}{l}\text { Kalium } \\
\text { (serum) }\end{array}$ & $\begin{array}{l}\text { Klorid } \\
\text { (serum) }\end{array}$ & $\begin{array}{l}\text { Reninaktivitet } \\
\text { (plasma) }\end{array}$ & $\begin{array}{l}\text { Aldosteron } \\
\text { (serum) }\end{array}$ & $\begin{array}{c}\text { Metabolsk } \\
\text { acidose }\end{array}$ \\
\hline PHA I & $\downarrow$ & $\uparrow$ & $\uparrow$ & $\downarrow$ & $\uparrow \uparrow$ & $\uparrow \uparrow \uparrow$ & ++ \\
\hline PHA II & $\downarrow$ & & $\uparrow$ & $\uparrow$ & $\downarrow$ & $\uparrow$ & \\
\hline Forbigående PHA & $\downarrow$ & $\uparrow$ & $\uparrow$ & $\downarrow$ & $\uparrow \uparrow$ & $\uparrow \uparrow \uparrow$ & ++ \\
\hline Adrenogenitalt syndrom & $\downarrow$ & $\uparrow$ & & $\downarrow$ & & $\downarrow \downarrow$ & + \\
\hline Bartters syndrom & $\downarrow$ & $\uparrow$ & $\downarrow$ & $\downarrow$ & $\uparrow$ & $\uparrow$ & Alkalose \\
\hline Selektiv hypoaldosteronisme & $\downarrow$ & $\uparrow$ & $\uparrow$ & $\downarrow$ & $\uparrow$ & $\downarrow$ & + \\
\hline Pyelonefritt & $\downarrow$ & & & & $\uparrow$ & $\uparrow$ & + \\
\hline
\end{tabular}

Tabell 3 Behandlingsprofiler og mistrivsel ved salttapende syndromer hos spedbarn. Tabellen er basert på Paal H.H. Lindenskovs oppsett

\begin{tabular}{|c|c|}
\hline Failure to thrive» & $\begin{array}{c}\text { Effekt av mineralo- } \\
\text { kortikoider }\end{array}$ \\
\hline
\end{tabular}

$\begin{array}{lccccc}\text { PHA I } & ++ & - & - & - & - \\ \text { PHA II } & + & - & - & - & + \\ \text { Sporadisk PHA } & ++ & - & + & - & - \\ \text { Adrenogenitalt syndrom } & ++ & -+ & - & - \\ \text { Bartters syndrom } & - & ++ & - & - & + \\ \text { Selektiv hypoaldosteronisme } & + & & & + \\ \text { PHA = pseudohypoaldosteronisme } & & & \end{array}$

På grunn av dilatert abdomen mistenkte man initialt en tarmperforasjon, muligens sekundært til et strangulert lyskebrokk med komplikasjoner i form av peritonitt og systemisk inflammatorisk respons. Dette ville igjen kunne gi en sirkulatorisk kollaps og utvikling av prerenal nyresvikt.

Ultralyd abdomen med doppler viste normal tarmperistaltikk og normalt strømningssignal $i$ a. mesenterica superior, og man fant heller ikke dilatasjon av tarmen. Det ble heller ikke påvist fri luft i bukhulen ved røntgenundersøkelse.

Ved innkomst hadde gutten forhøyet CRP, lavt platetall, samt koagulasjonsprøver forenlig med disseminert intravaskulær koagulasjon (DIC) og systemisk infeksjon. Pasienten fikk transfundert blodplater, erytrocytter og plasma. Pressorterapi i form av vasopressin og høydose noradrenalininfusjon ble startet etter PiCCO-målinger (pulse induced continuous cardiac output) som viste høyt hjerteminuttvolum kombinert med lav perifer motstand, tolket som septisk kapillardilatasjon. Ved ekkokardiografi fant man lett økte hastigheter ut av alle ostier forenlig med hyperkinetisk sirkulasjon.

Det ble høstet sparsomt med urin som var blakket via et kateter lernæringskateter Ch 6) som man med besvær fikk plassert. Kjemisk analyse av urin viste pyuri og proteinuri, men ingen utslag for nitritt.

De fleste urinveispatogene bakterier, med unntak for enterokokker, gir utslag for nitritt.
Man fant oppvekst av enterokokker i kateterurin, blod og ascitesvæske. Det ble satt i gang behandling med høye doser av cefotaksim, ampicillin og metronidazol for urosepsis. Ultralydundersøkelse viste forstørrede nyrer med økt ekkosignal, fortykket vegg i urinblæren, samt utvidede nyrebekken og urinledere.

Det ble konstatert alvorlig laktacidose, hyponatremi, hyperkalemi, hypermagnesemi, hyperfosfatemi, hypoalbuminemi, høy karbamidkonsentrasjon, høyt kreatininnivå og anemi. Klinisk og biokjemisk var altså pasienten i nyresvikt uten respons på medikamentell diuresestøtte, og peritoneal dialyse ble iverksatt.

Pasienten hadde en fulminant bakteriell sepsis ledsaget av disseminert intravaskulær koagulasjon. Agens viste seg å være enterokokker, høyst sannsynlig utgående fra urinveier. Ettersom foreldrene aldri hadde observert en normal urinstråle, og at man ved ultralydundersøkelse av urinveier fant blærehypertrofi og bilateralt dilaterte samlesystemer, var det grunn til å anta at det forelå urinveisobstruksjon i form av medfødte urethraklaffer.

Blodprøve tatt ved innleggelse viste forhøyet reninaktivitet og aldosteronnivå i plasma, forenlig med såkalt pseudohypoaldosteronisme (PHA).

Resturin som følge av obstruksjoner i urinveiene, kan gi den vannfase bakterier trenger for å vokse opp. Forhøyet blæretrykk generert av utløpsobstruksjon kan videre for- årsake vesikoureteral refluks med bakteriell spredning til nyrebekken, utvikling av interstitiell nefritt og videre hematogen spredning (fig 1). Forhøyet intraabdominalt trykk ved blæretømming kunne videre forklare pasientens lyskebrokk.

Til tross for pågående intensivbehandling forverret tilstanden seg og pasienten døde tredje døgn etter innkomst. Ved obduksjon fant man urethraklaffer, ekstremt dilaterte urinledere, utvidede nyrebekken på begge sider, nekrotisk venstre nyre, puss i høyre nyrebekken og fortykket vegg i urinblæren.

\section{Diskusjon}

Grunnet avløpshinder i urinveiene i form av urethraklaffer, fikk pasienten en urinveisinfeksjon som utviklet seg til en livstruende systemisk infeksjon. I tillegg oppsto den endokrine forstyrrelsen pseudohypoaldosteronisme (PHA) som kan forklare deler av symptombildet forut for og under det dramatiske septiske forløpet. Vår påstand er at forbigående pseudohypoaldosteronisme er en oversett tilstand hos spedbarn med obstruktive uropatier. Dette er ingen hyppig tilstand hos spedbarn, men ikke desto mindre kan følgene bli alvorlige hvis ikke diagnosen stilles $i$ tide og behandling rettes mot underliggende årsak. Tilstanden normaliseres ved kirurgisk korreksjon av den obstruktive uropati.

Pseudohypoaldosteronisme kan forekomme familiært, men opptrer som oftest forbigående, og da som en følge av urinveisobstruksjon. Ved alle former for denne forstyrrelsen finner man paradoksalt nok svært 
høye verdier av aldosteron i plasma. Mekanismen for dette er sannsynligvis en ACTHmediert kompensatorisk syntese av aldosteron grunnet redusert aldosteronrespons i distale nyretubuli (fig 2). På grunn av salttap har barna dårlig vekstutvikling og viser generell mistrivsel (failure to thrive). I tillegg finner man varierende grad av hyperkalemi, metabolsk acidose, vanntap og kompromittert perifer sirkulasjon (fig 2) (1-5).

Cheek \& Perry beskrev i 1958 en familiær form av pseudohypoaldosteronisme i spedbarnsalder som en salttapende tilstand med normal nyre- og binyrefunksjon, siden kjent som PHA type I hvor cyanoseanfall er beskrevet som et debutsymptom (2). Fenotypisk arter den seg enten som renal eller en generalisert aldosteronresistens med henholdsvis et mildt klinisk forløp ledsaget av lett hyponatremi eller et mer komplekst symptombilde med aldosteronresistens i monocytter, lymfocytter, spyttkjertler, svettekjertler og nyretubuli $(6,7)$.

Som PHA type I opptrer også PHA type II familiært, men er sjeldnere (8). PHA type II skiller seg fra PHA type I ved hypertensjon, lave verdier av renin, en hyperkloremisk snarere enn en hypokloremisk metabolsk acidose uten salttap (tab 2). Ved PHA type II anbefales derfor saltrestriksjon, i motsetning til ved PHA type I som behandles med salttilskudd (tab 3 ).

Vår pasient hadde ikke noen av de familiære formene, men snarere den forbigående formen først beskrevet av Rodrìguez-Soriano og medarbeidere i 1983 (9). Fire av seks pasienter i deres materiale var assosiert med obstruktiv uropati. Den obstruktive uropatien kan skyldes ureteropelvin overgangsstenose, bilateral terminal ureterstenose, ektopisk ureterocele, meatusstenose og ikke minst urethraklaffer. I en videre forstand tas også vesikoureteral refluks med blant de obstruktive uropatier ettersom tilstanden forårsaker økt trykk i nyrebekkenet $(10,11)$. Forbigående pseudohypoaldosteronisme har vært beskrevet av flere $(4,10-13)$, og debuterer etter nyfødtperioden med vage symptomer i form av langsom vektoppgang, tegn til mistrivsel og etter hvert oppkast og dehydrering. Mistrivsel og manglende vektoppgang ses også ved medfødt hjertefeil, medfødt metabolsk sykdom eller ved mindre alvorlige tilstander som mangelfull dieteknikk og hypertrofisk pylorusstenose. I en kasustikk ble tilstanden beskrevet ved hypertrofisk pylorusstenose, sannsynligvis som følge av urinveisinfeksjon (14). Udiagnostisert vil forbigående pseudohypoaldosteronisme kunne progrediere og $\mathrm{i}$ fulminant form presentere seg som en salttapende nefropati med hyperkalemi, hyponatremi og normo- eller hypokloremisk metabolsk acidose (fig 2). Diagnostisk for tilstanden er svært forhøyet aldosteronnivå og reninaktivitet i plasma, som begge er reversible ved korreksjon av obstruktiv uropati (fig 2). Det er imidlertid beskrevet et tilfelle av persisterende pseudohypoaldosteronisme grunnet ensidig dysplastisk nyre som følge av vesikoureteral refluks (3).

Vår pasient hadde pneumthorax ved fødselen. Sammenhengen mellom spontant oppstått pneumothorax ved fødsel og obstruktiv urinveisanomali er velkjent $(15,16)$. En mulig årsak kan være hypoplastiske lunger som følge av varierende grader av oligohydramnion $(17,18)$. Spontan pneumothorax er også beskrevet ved forbigående pseudohypoaldosteronisme (19). Vi foreslår at ved spontant oppstått pneumothorax hos fullbårne som ikke har vært eksponert for overtrykksventilasjon, bør man vurdere muligheten for om det kan foreligge urinveisanomalier med eller uten pseudohypoaldosteronisme.

Forbigående pseudohypoaldosteronisme kan videre forekomme uten at det foreligger obstruktiv uropati så som ved pyelonefritt (13). Det er beskrevet biokjemiske forandringer ved pyelonefritt som ved en normokalemisk pseudohypoaldosteronisme med natrium i nedre normalområde i startfasen av infeksjonen, og med vedvarende forhøyet nivå av renin og aldosteron hos pasienter med arr påvist ved DMSA-scintigrafi (20). Enkelte forfattere vil derfor hevde at infeksjonen forårsaker pseudohypoaldosteronisme, og ikke den obstruktive uropati (21). Biokjemiske profiler og behandlingsprofiler for ulike typer av tilstanden og noen aktuelle differensialdiagnoser fremgår av tabell 2 og 3 .

Vi konkluderer med at vage symptomer som dårlig vektoppgang og tegn på mistrivsel hos spedbarn kan skrive seg fra forbigående pseudohypoaldosteronisme sekundært til obstruktiv uropati. Koblet med sekundær infeksjon utgått fra urinveiene, kan tilstanden bidra til utvikling av sirkulatorisk kollaps. Måling av blodtrykk, elektrolyttmålinger i blod og urin, ultralydundersøkelse av urinveiene samt måling av reninaktivitet og aldosteronnivå $i$ plasma er aktuelt å benytte for å avklare dette. Aller viktigst er imidlertid å oppdage obstruktiv uropati hos spedbarn i tide.

Pasientens foreldre har gitt samtykke til at artikkelen blir publisert.

\section{Paal H.H. Lindenskov (f. 1962)}

er dr.med., spesialist i anestesiologi og i barnesykdommer.

Forfatter har fylt ut ICMJE-skjemaet og oppgir ingen interessekonflikter.

\section{Arild Rønnestad (f. 1956)}

er dr.med., spesialist i barnesykdommer Forfatter har fylt ut ICMJE-skjemaet og oppgir følgende interessekonflikter: Han har mottatt honorar for ekspertuttalelse for Norsk Pasientskadeerstatning

\section{Hans Skari (f. 1963)}

er dr.med., spesialist i generell kirurgi og i barnekirurgi.

Forfatter har fylt ut ICMJE-skjemaet og oppgir ingen interessekonflikter.
Litteratur

. Buzi F, Bezante T, Brunori A et al. Pseudohypoaldosteronism: report of a case presenting as failure to thrive. J Pediatr Endocrinol Metab 1995 8: 61-5

2. Cheek DB, Perry JW. A salt wasting syndrome in infancy. Arch Dis Child 1958; 33: 252-6.

3. Giapros VI, Tsatsoulis AA, Drougia EA et al. Rare causes of acute hyperkalemia in the 1st week of life. Three case reports. Pediatr Nephrol 2004 19: $1046-9$

4. Levin TL, Abramson SJ, Burbige KA et al. Salt losing nephropathy simulating congenital adrenal hyperplasia in infants with obstructive uropathy and/or vesicoureteral reflux-value of ultrasonography in diagnosis. Pediatr Radiol 1991; 21 413-5.

5. Speiser PW, Stoner E, New MI. Pseudohypoaldosteronism: a review and report of two new cases. Adv Exp Med Biol 1986; 196: 173-95.

6. Sartorato P, Khaldi Y, Lapeyraque AL et al. Inactivating mutations of the mineralocorticoid receptor in Type I pseudohypoaldosteronism. Mol Cell Endocrinol 2004; 217: 119-25.

7. Riepe FG, Krone N, Morlot M et al. Autosomaldominant pseudohypoaldosteronism type 1 in a Turkish family is associated with a novel nonsense mutation in the human mineralocorticoid receptor gene. J Clin Endocrinol Metab 2004; 89: 2150-2

8. Schambelan M, Sebastian A, Rector FC Jr. Mineralocorticoid-resistant renal hyperkalemia without salt wasting (type II pseudohypoaldosteronism): role of increased renal chloride reabsorption. Kidney Int 1981; 19: 716-27.

9. Rodríguez-Soriano J, Vallo A, Oliveros R et al. Transient pseudohypoaldosteronism secondary to obstructive uropathy in infancy. J Pediatr 1983; 103: $375-80$

10. Klingenberg C, Hagen IJ. Transient pseudohypoaldosteronisme hos spedbarn med vesikoureteral refluks. Tidsskr Nor Lægeforen 2006; 126: 315-7.

11. Pumberger W, Frigo E, Geissler W. Transient pseudohypoaldosteronism in obstructive renal disease. Eur J Pediatr Surg 1998; 8: 174-7.

12. Bülchmann G, Schuster T, Heger A et al. Transient pseudohypoaldosteronism secondary to posterior urethral valves-a case report and review of the literature. Eur J Pediatr Surg 2001; 11: 277-9

13. Maruyama K, Watanabe H, Onigata K. Reversible secondary pseudohypoaldosteronism due to pyelonephritis. Pediatr Nephrol 2002; 17: 1069-70.

14. Wang YM. Pseudohypoaldosteronism with pyloric stenosis-a patient report. J Pediatr Endocrinol Metab 1997; 10: 429-31

15. Bashour BN, Balfe JW. Urinary tract anomalies in neonates with spontaneous pneumothorax and/or pneumonediastrnum. Pediatrics 1977; 59 (suppl): 1048-9

16. Ashkenazi S, Merlob P, Stark H et al. Renal anomalies in neonates with spontaneous pneumothorax - incidence and evaluation. Int J Pediatr Nephrol 1983; $4: 25-7$

17. Hooper SB, Harding R. Fetal lung liquid: a major determinant of the growth and functional development of the fetal lung. Clin Exp Pharmacol Physiol 1995: 22: 235-47.

18. Kizilcan F, Tanyel FC, Cakar N et al. The effect of low amniotic pressure without oligohydramnios on fetal lung development in a rabbit model. Am J Obstet Gynecol 1995: 173: 36-41.

19. Watanabe T, Yamazaki A. Pneumothorax and transient pseudohypoaldosteronism in an infant with hydronephrosis. Pediatr Nephrol 2003; 18: 62-4.

20. Rodríguez-Soriano J, Vallo A, Quintela MJ et al. Normokalaemic pseudohypoaldosteronism is present in children with acute pyelonephritis. Acta Paediatr 1992; 81: 402-6.

21. Nandagopal R, Vaidyanathan P, Kaplowitz P. Transient pseudohypoaldosteronism due to urinary tract infection in infancy: a report of 4 cases. Int J Pediatr Endocrin 2009; 2009: 195728.

Mottatt 11.11. 2011, første revisjon innsendt 22.2. 2012, godkjent 25.5. 2012. Medisinsk redaktør Siri Lunde. 


\section{Kommentar}

\section{Vage symptomer - fatal utgang}

Engelsk oversettelse på www.tidsskriftet.no

Urosepsis i løpet av de første levemånedene er ikke helt uvanlig og forekommer hyppigst hos gutter, først og fremst pga. urogenitale misdannelser (1). Urethraklaffer, som kun forekommer hos gutter, manifesterer seg på ulike måter, og ved påvisning i fosterlivet kan uttalt hydronefrose gi grunnlag for avlasting prenatalt (2). Postnatalt vil en urosepsis kunne være det første symptomet om da ikke noen allerede har reagert på at gutten har en svak urinstråle. Obstruksjonen kan i enkelte tilfeller være såpass beskjeden at tilstanden først avklares etter flere år når barnet henvises pga. urininkontinens, ev. i voksen alder (3).

Den aktuelle sykehistorien er et godt eksempel på hvor utfordrende det kritisk syke spedbarnet kan fremstå. Opplysning om svak urinstråle må føre til videre bildediagnostikk. Ved ultralydundersøkelse av urinveiene vil man kunne påvise hydronefrose og fortykket blærevegg, når det foreligger urethraklaffer. Ultralyd er imidlertid en metode som er avhengig av undersøkerens erfaring og kompetanse, og påvisning av en eventuell hydronefrose forutsetter at pasienten er adekvat hydrert. Selve diagno- sen må verifiseres ved miksjonsuretrocystografi (MUCG), fordi bl.a. både en nevrogen og en ikke-nevrogen urinblære vil kunne gi det samme ultralydfunnet (4).

Barnets dårlige vektoppgang og generelt dårlige trivsel (failure to thrive) tilsier i seg selv en grundig utredning. En av årsakene til dette symptomkomplekset kan være en øvre urinveisinfeksjon, selv om barnet ikke har feber. Betydningen av å undersøke urinen hos alle spedbarn med uklare symptomer eller funn kan ikke understrekes ofte nok. Dette gjelder ikke bare ved mistanke om en bakteriell urinveisinfeksjon, men også ved tilstander som direkte eller indirekte rammer nyretubuli og/eller -interstitiet. Ikke bare kunnskap om elektrolytter, men også om $\mathrm{pH}$, aminosyrer (metabolsk screening) og glukose kan være avgjørende for videre diagnostikk.

Kort summert understreker kasuistikken at opplysning om svak urinstråle må forfølges bildemessig, at generelt dårlig trivsel alltid må utredes og at undersøkelse av urinen er svært viktig ved uklare tilstander hos spedbarn.

\author{
Hans-Jacob Bangstad \\ h.j.bang@online.no \\ Barnemedisinsk avdeling \\ Oslo universitetssykehus, Ullevål
}

Hans-Jacob Bangstad (f. 1949) er spesialist i pediatri og seksjonsoverlege.

Forfatter har fylt ut ICMJE-skjemaet og oppgir følgende interessekonflikter: Han har mottatt reisestøtte fra Ferring.

\section{Litteratur}

1. Mesrobian HG. Urologic problems of the neonate: an update. Clin Perinatol 2007; 34: 667-79, viii. viii.

2. Carr MC, Kim SS. Prenatal management of urogenital disorders. Urol Clin North Am 2010; 37: 149-58.

3. Khursigara N, McGuire BB, Flood H. Late presentation of posterior urethral valves. Can J Urol 2011; 18: 5739-41.

4. Jayanthi VR, Khoury AE, McLorie GA et al. The nonneurogenic neurogenic bladder of early infancy. J Urol 1997; 158: 1281-5.

Mottatt 18.6. 2012 og godkjent 22.6. 2012. Medisinsk redaktør Siri Lunde. 